\title{
Horticultural Crops Production Potentials and Challenges Assessment in Arsi Zone, Oromia-Ethiopia
}

\author{
Diriba-Shiferaw G. ${ }^{*}$, Hailu-Duguma M. ${ }^{2}$, Mebrat Tola ${ }^{3}$ \\ ${ }^{1}$ Department of Horticulture and Plant Sciences, College of Agriculture and Environmental Science, Arsi \\ University, Asella, Ethiopia \\ ${ }^{2}$ Department of Horticulture, College of Agriculture and Veterinary Sciences, Ambo University, Ambo, Ethiopia \\ ${ }^{3}$ Department of Agricultural Economics, College of Agriculture and Environmental Science, Arsi University, \\ Asella, Ethiopia
}

*Corresponding Author: Diriba-Shiferaw G., Department of Horticulture and Plant Sciences, College of Agriculture and Environmental Science, Arsi University, Asella, Ethiopia

\begin{abstract}
Horticultural crops are one of the most important agricultural commodities produced in Ethiopia for both commercial and consumption purposes. However, due to different constraints the potential of the crops was not utilized to the full extent by economic entities of the different areas. Thus, this research study was made to identify performances, potentials and opportunities and constraints of horticultural crops production in Arsi zone, Oromia Regional State, Southeastern Ethiopia in 2017 with the specific objectives of describing the major potentials of the commodities; and identifying the constraints and opportunities for horticultural commodities in the study areas. From the zone, five horticulture commodities producing districts were selected purposively for their capacity of producing the commodities. The data were collected from both primary and secondary sources. The primary data were collected using interview guided questionnaires from 160 respondents of different levels and types of horticulture commodities and five focus group discussions of horticulture commodities producers from the five districts. Descriptive and inferential statistics; and constraints and opportunities analysis were used to analyze the data. From the total horticultural crops results showed that education level of household, horticulture farming experience, land size used for horticulture farming, amount of fertilizer used, access to extension services and family size of house hold were variables those significantly influenced the production and supply of horticulture at farmer's level. Pests (diseases, insects, weeds), limited supply of agricultural inputs, limited knowhow and skill, low price of produce and poor linkage with markets were major producers' constraints identified in the study areas. Supply shortage, lack of organized market information, low produce quality, loss of produce due to poor handling, competition with unlicensed traders, price fluctuation and lack of support from government bodies were major market related constraints studied on the horticultural crops production of the areas. Thus, horticulture crops are affected by several aforementioned constraints those influenced the efficiency and competitiveness of the producers in the study areas. The recommendations forwarded to accelerate the horticulture crops production are strengthening extension system and other supportive services; supporting producers in order to use improved agricultural inputs, modern technologies, controlling diseases and insects (pests) problems; constructing additional irrigation and storage facilities; organizing, strengthening and supporting horticultural crops producer's cooperatives and organizing the producers are very important.
\end{abstract}

Keywords: horticulture commodities, potentials, opportunities and constraints, districts

\section{INTRODUCTION}

In Ethiopia Agriculture is the most important sector, crucial for the country's food security and the livelihoods of nearly $85 \%$ of its people, and serving as the engine for the country's development strategy, Agriculture Development Led Industrialization. It continues to be the most dominant aspect of the Ethiopian economy, accounting for nearly $46 \%$ of GDP, $73 \%$ of employment, and nearly $80 \%$ of foreign export earnings (ATA, 2014). Having all these importance, agriculture continues to face a number of problems and challenges. The major ones are adverse climatic conditions, lack of appropriate land use system resulting in soil and other natural resources degradation, limited use of improved agricultural technologies, the predominance of subsistence agriculture and lack and/or absence of business oriented agricultural production system, limited or no access to market facilities resulting in low participation of the smallholder farmers in value chain or value addition of their produces (Bezabih, 2010). 
In other way, globalization and expanding international markets as well as the fast-growing middle and high income classes in many developing countries offer opportunities for developing country producers like Ethiopia to operate in emerging national and international markets (Dolan and Humphrey, 2004). These opportunities can be utilized efficiently through potentials development approach that helps to boost production, productivity and efficiency of small holders and other actors in agricultural productivities. Therefore, it is becoming increasingly crucial for policy makers to focus on development approach in agricultural potentials in order to develop efficient agricultural values; those can increase significantly the rate and scope of agricultural and industrial growth of developing countries (UNIDO, 2009).

Various types of fruits and vegetable crops are grown in Ethiopia under rain-fed and/or irrigation systems (Alemayehu et al., 2010). Ethiopia has favorable climate and edaphic conditions for the production of tropical, sub-tropical and temperate fruits and vegetables. However, the amount and mode of production is still weak (EHDA, 2011). Horticultural crops play important role in poverty alleviation through employment generation, improving the feeding behavior of the people and creating opportunities particularly for poor farmers (Weignberger and Lumpkin, 2005).

The country's agricultural potential for food production is known to be immense and over 90 percent of its export earnings come from this sector. Coffee, oil seeds, spices, fresh fruit and vegetables contribute the largest portion of the export earnings. Available sources indicate that a total of 10 million tonnes of cereals, one million ton pulses and oil crops, seven million tonnes of vegetables, 0.7 million tonnes of root and tuber crops, 0.25 million tonnes of coffee, 0.23 million tonnes of fruits are estimated to be produced annually $(M o A, 1999)$. At the national level, agriculture is important as a vehicle for addressing food security problems. Stimulating agricultural growth will therefore be the major instrument for increasing the income of the country and households in particular with which food can be bought domestically and imported from abroad. The largest groups of people in Ethiopia who suffer from food insecurity are the rural poor who have insufficient land and other resources to provide sufficient income or food. It is generally agreed that the resources available to researches in Ethiopia are scarce, and experimentation is the most costly phase of a research program, hence researchers must make sure that the possible solutions to identified problems have a high chance of success. Therefore, problems in agriculture must be carefully identified, formulated and prioritized for concerted experimentation.

There is a need to identify factors limiting production and productivity of horticultural crops in Arsi zone. It is imperative to understand what is known and what can be done, and what is actually practiced by farmers in the zone and it is important to work as hard as possible on the formulation of problems before searching for solutions. Farms in the Arsi zone have substantially lower yields of major horticultural crops compared to other areas in the region, e.g. East Shewa zone (CSA, 2011). Even though the zone is an ideal place for market oriented horticultural crops, the sector is subsistence and low level of development in access to modern technology, market, and improved variety hinders productivity (Mekonen, 2012). Therefore, this study was initiated with the general objective of assessing the productivity and bottlenecks of horticultural crops production and supply for the users in Arsi Zone, Oromia, Ethiopia; with specific objectives of formulating the research problems for the Horticulture section of Arsi University for further experimental use, which is responsible for Arsi Zone, and identifying opportunities and constraints of the zone in relation to horticultural crops production and productivity.

\subsection{Research Questions}

There were different questions that were answered to address the objectives of the study. The research questions were focused on these major questions: -

- What are the potentials available in the study areas regarding horticultural crops productions?

- What are the constraints that hinder the competitiveness of the whole sector in the area?

- What are the opportunities available for production and productivity of the crops in the study areas?

\subsection{Significance of the Study}

This study generated important information useful to formulate horticulture crops production programs and guidelines for interventions that would improve efficiency of the horticulture crops production 
system. The potential users of the results of this study would be research centers, development organizations, farmers, traders, policy makers, and extension service providers, governmental and nongovernmental organization, who want to introduce interventions of horticulture crops production. Furthermore, this study might be used as reference for further researches.

\subsection{Scope of the Study}

This study was conducted in five districts of Arsi zone, Oromia Regional State, Ethiopia from 12 rural kebeles of the zone, with specific crop category; of horticultural commodities within one-year time boundary. The data were collected from sample households of 12 rural kebeles of the five districts which was purposively selected due their potentiality from their previous data analysis of the zone data in the study areas. The study employed constraints and opportunities analysis approach that analyzed the performance of farmers in horticulture crops production in the study areas.

\subsection{Limitations of the Study}

The study was limited to only 12 horticulture crops producing kebeles and the researcher didn't cover all the crops producing kebeles of the five districts because of shortage of budget, logistics and time limitation. It was also limited to potentials, constraints and opportunities analysis approach. Furthermore, Since Ethiopia has wide range of diverse agro-ecologies, institutional capacities, organizations and environmental conditions, the result of the study might have been limitations of making generalizations and making them applicable to overall country. However, it may be useful for areas with similar context with the study areas as a basis.

\section{RESEARCH DESIGN AND MeThOdOLOGY}

\subsection{Description of Study Areas}

This study was conducted in Arsi Zone, Oromia Regional State, Southeastern Ethiopia in five potential horticultural crops producing districts (namely Digelu-Tijo, Lemu-Bilbilo, Hetosa, Tiyo and ZiwayDugda Districts,) in both irrigation and rain-fed production and different types of irrigations (Tables 1 and 2). All districts are more known in horticultural crops production and productivity in the Zone as the previous data of the zone indicated. The districts are located surrounding central city of the zone, Arsi, which is found at $175 \mathrm{~km}$ Southeastern of Addis Ababa. The districts include high lands, middle and low lands (AZADO, 2014).

Table1. Quantitative production of horticultural crops in terms of acreage coverage

\begin{tabular}{|c|c|c|c|c|c|}
\hline S.No & District Name & $\begin{array}{c}\text { Irrigation } \\
\text { Production of } \\
\text { Horticulture Crops } \\
\text { (ha), 2015/16 } \\
\end{array}$ & $\begin{array}{c}\text { Total Production } \\
\text { of Horticulture } \\
\text { Crops (ha), } \\
2015 / 16 \\
\end{array}$ & $\begin{array}{c}\text { Production of } \\
\text { Horticulture } \\
\text { Crops (ha), } \\
\text { 2015/16 } \\
\end{array}$ & Remarks \\
\hline 1 & Amigna & 2968 & 4432 & 6318 & \\
\hline 2 & Asako & 7625 & 11182 & 16066 & \\
\hline 3 & Bale & 2089 & 3156 & 4524 & \\
\hline 4 & Colle & 4468 & 6500 & 8744 & \\
\hline 5 & Diksis & 203 & 244 & 138 & \\
\hline 6 & Digelu-Tijo & 9137 & 12921 & 19942 & Selected \\
\hline 7 & Dodota & 887 & 1415 & 1680 & \\
\hline 8 & Gololcha & 7373 & 11689 & 16446 & \\
\hline 9 & Guna & 198 & 333 & 424 & \\
\hline 10 & Hetosa & 140 & 2370 & 3080 & Selected \\
\hline 11 & H/Wabe & 1359 & 2432 & 2986 & \\
\hline 12 & Jaju & 3585 & 7081 & 7614 & \\
\hline 13 & Lemu-Bilbilo & 6759 & 8207 & 14090 & Selected \\
\hline 14 & Hetosa & 2453 & 4638 & 5510 & \\
\hline 15 & Marti & 2649 & 5174 & 5694 & \\
\hline 16 & Munessa & 2832 & 5165 & 5342 & \\
\hline 17 & Robe & 4628 & 6986 & 8232 & \\
\hline 18 & Seru & 1557 & 2959 & 2960 & \\
\hline 19 & Shirka & 8904 & 13063 & 18424 & \\
\hline 20 & Sire & 514 & 857 & 1112 & \\
\hline 21 & Sude & 2753 & 3328 & 6168 & \\
\hline
\end{tabular}


Horticultural Crops Production Potentials and Challenges Assessment in Arsi Zone, Oromia-Ethiopia

\begin{tabular}{|c|c|c|c|c|c|}
\hline 22 & Xanna & 4753 & 7849 & 9540 & \\
\hline 23 & Xiyo & 2263 & 3612 & 4916 & Selected \\
\hline 24 & Ziway-Dugda & 10836 & 17708 & 20972 & Selected \\
\hline & Total & 90933 & 143301 & 190922 & \\
\hline
\end{tabular}

Table2. Hectare for horticultural crops production in terms of irrigation types utilized by the communities in $2015 / 16$

\begin{tabular}{|c|c|c|c|}
\hline S.No & Types of Irrigation & Production of Horticulture Crops (ha) & Remarks \\
\hline 1 & Traditional & 64479 & \\
\hline 2 & Modern & 7759 & \\
\hline 3 & Pump & 16979 & \\
\hline 4 & Ground water & 1530 & \\
\hline 5 & Pond/haro/ & 186 & \\
\hline & Total & $\mathbf{9 0 9 3 3}$ & \\
\hline
\end{tabular}

\subsection{Conceptual Frame Work}

In order to analyze determinants of production of the crops conceptual framework was used. It comprises dependent and different explanatory variables. The dependent variable was amount of horticultural crops of producers. The explanatory variables were categorized in to different social, demographical, technological, economical, marketing, financial and infrastructural factors specified to analyze determinants of horticultural crops at producers' level in the study areas.

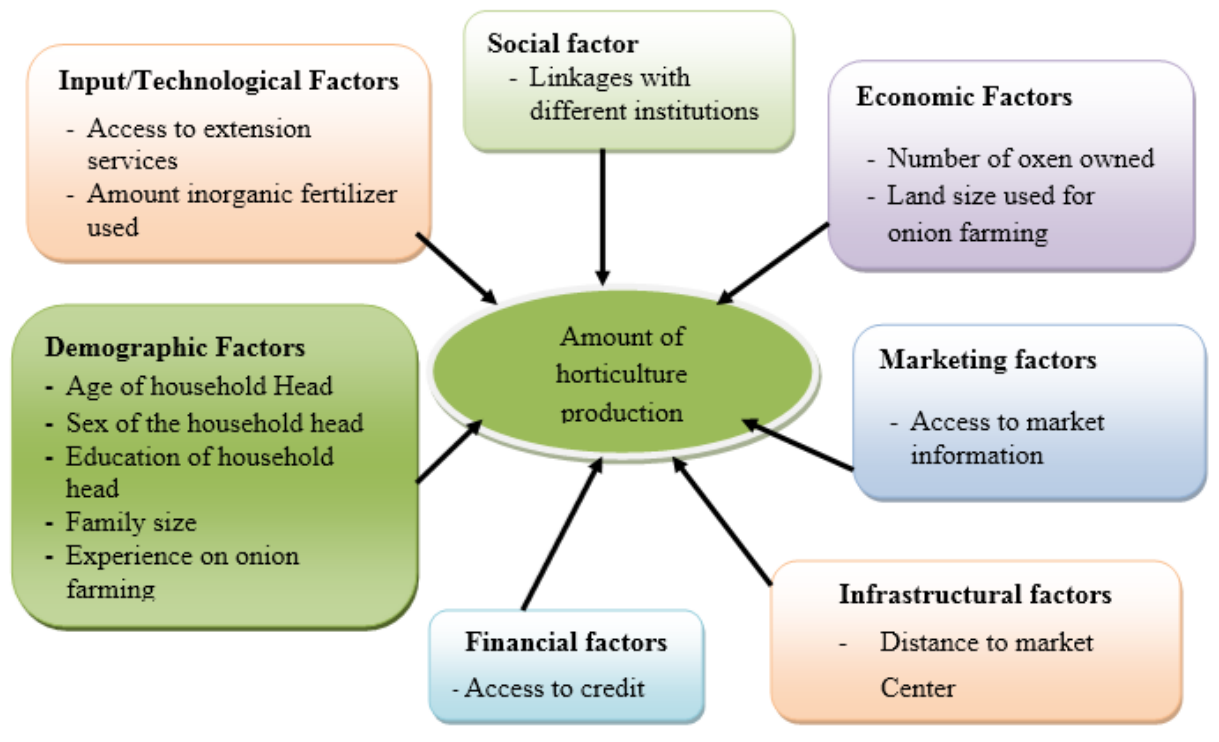

Figure1. Conceptual frame work developed by researchers

\subsection{Research Design and Population of the Study}

Survey type of research design was used to conduct this study. The population of the study covered the five districts of the zone which were selected purposively because of they are known in horticultural crops production from 24 districts of Arsi Zone. The target populations of the study were also covered about 12 kebeles producers which were randomly selected in each kebeles in the study areas. According to data obtained from five districts' Irrigation Development Authority Offices; totally there were 90933ha of land produced in 2015/16 in 24 districts using different irrigation types in the study areas (Table 2).

\subsection{Sampling Techniques}

Purposive sampling technique was used to draw the sampling units of the study. Totally there are 24 districts in the zone and from these 12 kebeles were used as representative for data collection. At the first stage, with the consultation of districts' Irrigation Development Authority and Agriculture and Rural Development Offices experts and based up on secondary data obtained from offices; 12 horticulture crops growers' kebeles were purposively selected from the five districts due to all of them are potentially producing the crops. Number of sample kebeles was decided by researcher to cover $21 \%$ of horticulture crops growing kebeles' of the districts. 


\subsection{Source and Data Collection}

In order to meet the objective of the study, the data required for the study were collected from primary and secondary data sources. Primary data were collected from producers. For primary data collection methods semi-structured interview schedule or interview guided questionnaires, key informants interview and focus group discussions were used.

To collect primary data seven Technical Assistants (enumerators) working in the university were selected and trained on how to conduct and approaches interviewing the sample members for each sample categories. The researchers preferred Technical Assistants because of they have close relationship with the study and producing farmers since they are working together and that helps to avoids on response due to doubtful and worries and to minimize the technical errors. Districts Cooperative promotion and Irrigation Development Authority Offices experts were also used to help the data collection and facilitation of the work.

Primary data also collected from horticulture crops growers by conducting focus group discussions. One focus group discussion per kebele was conducted with more than 10 members per group by selecting respondents randomly. To make the communication easier during collection of data from the respondents, the interview guide questionnaire was prepared in English and translated to "Afaan Oromo". Secondary data was collected from government organizations such as Districts and Zonal Irrigation Development Offices and Agricultural Development Offices, magazines, journals, previous research report, etc.

\subsection{Methods of Data Analysis and Procedures}

The questionnaires were checked for clarity and consistency in answering questions. This was followed by coding of answers and data entry into the computer for analysis. Statistical package for social science (SPSS) version 20.0 and STATA version 11.0 were used for entering data to computer and analysis of data.

\subsubsection{Descriptive and Inferential Statistics}

These methods of data analysis refer to the use of percentages, means, Standard deviation, and graph in the process of examining and describing services and household characteristics.

\subsubsection{Constraints and Opportunities Analysis}

Constraints and opportunities analysis was used to analyze the challenges and opportunities for technological, institutional and organizational innovation across the crops productions. Both production and related constraints and opportunities were analyzed.

\subsection{Operationalizing the Research}

Two types of variables were used in the research. These are dependent and independent (explanatory) variables.

\subsubsection{Dependant variable}

Quantity of horticulture crops produced:-It is a continuous variable representing dependant variable. It is the amount of horticulture crops actually produced by households to family consumption and market in the study year and measured in quintal.

\subsubsection{Independent variables}

1. Age of the household head:- It is a continuous variable and measured in years. Aged households are believed to be wise in resource use; on the other hand young household heads have long investment horizon and it is expected to have either positive or negative effect on volume of horticulture crops production.

2. Sex of the household head:- This is a dummy variable. No sign could be expected a prior for this variable. It could take positive or negative signs of coefficients.

3. Education level of household head:-This is a discrete variable that is measured by year of schooling. Education increases farmers' ability to get and use information. Since households who have better knowledge are assumed to adopt better production practices, this variable is assumed to have positive relation with farm level and production capacity. 
4. Family size:- Family size of a respondent is a continuous variable measured in terms of number of family members in the household. No sign could be expected a prior for this variable. It could take positive or negative signs of coefficients.

5. Number of oxen owned:- Being a power for plowing horticulture crops production would increase as farmers increased their number of oxen ownership. The expected influence is positive on supply. It is a continuous variable and is expected to affect the production positively. This is because those farmers who have their own oxen can reduce their cost of production (oxen rent) and can plough their land on time and as a result, be able to produce more horticulture crops and supply for the market.

6. Experience on horticulture crops farming: It is a continuous variable measured in years, which refers to the number of years the producer engaged in horticulture crops producing activity, having cumulative knowledge on how to produces the crops. As farmers get more experience in production the crops, the probability to have potential horticulture crops production would be higher. Farmers with longer farming experience are expected to be more knowledgeable and skillful (Ayelech, 2011). A study conducted by Abay (2007) also confirmed that farming experience had positive relationship with production and marketable supply of vegetable crops. Therefore a positive relationship between the variable and amount of horticulture crops supplied to the market was hypothesized.

7. Land size used for horticulture crops farming:- This is a continuous variable that is measured by hectares. Different studies indicated that the more land used for horticulture commodities/crops farming the more will be the production and supply to the market.

8. Access to credit:- This is a dummy variable, which assumes a value of one if the producers have credit access and zero if not. Access to credit could enhance the financial capacity of the farmer to purchase the necessary inputs and increases output. Therefore, it was hypothesized that access to credit would have positive influence on quantity of horticulture produce.

9. Amount of fertilizer used:- It is the most important variable in agricultural activities. If the farmers use the amount of fertilizers (DAP \& Urea) as recommended agronomically and quantity of horticulture crops produced can be positively affected. It was continuous variable that is measured by $\mathrm{kg}$.

10. Linkages with institutions:- It is dummy variable and takes the value of one if the households have linkages with different institutions like marketing organizations and producers associations otherwise zero. If the famers are belonging to an association as members or having linkage with marketing organizations, it help them to improve understanding about crops productions and strengthen the vertical and horizontal relationship of the farmers with associations or organizations. Therefore, it was hypothesized that linkages with different institutions would have positive influence on quantity of supply to the market.

11. Access to extension service:- This is measured as a dummy variable giving value of one if the farmers had access to extension service and zero if not. According to Adugna (2009), the aim of the extension service is to introduce farmers with new and improved agricultural inputs for better methods of increasing production and productivity in turn that increase marketable supply. Ayelech (2011) found that if fruit producer gets extension service, the amount of fruits supplied to the market increases. So, this variable was assumed to have positive relation with farm of horticulture crops.

12. Access to market information:- This is measured as a dummy variable giving value of one if the farmers had access to market information and zero if not. Farmers marketing decisions are based on market place and price information. Abay (2007) conclude that those farmers who had better information is to be expected to supply more fruit to the market. Therefore, it was hypothesized that market information is positively related to horticulture crops production and marketing.

13. Distance to market center:- It is a continuous variable that is measured in kilometers which farmers spent time to sell their product to the market. Different studies (Adugna, 2009 and Abay, 2007) indicated particularly, rural communities in remote areas suffer from lack of transportation facilities. The closer to the market the lesser would be the transportation cost and time spent. Therefore, it was hypothesized that this variable is negatively related to marketable supply of horticulture crops production. 


\section{RESULTS AND DISCUSSION}

This chapter presented the major findings of the study and its discussion. It has two main sections. The first section deals with descriptive and inferential statistics of the sample households. The second section deals with the major constraints and opportunities of horticulture crops productions/functions in the study areas.

\subsection{Descriptive Analysis Results}

\subsubsection{Demographic Characteristics of Sample Households}

The major variables used to describe the demographic characteristics of sample producers include gender of the household, age, marital status, family size and education level and these factors significantly influenced the crop production (Table 3 ). The results of the of study indicated that the age of horticultural crops producing household showed variation; thus the age of horticultural crops producing household respondents ranged from 22 to 77 with a mean age of 41.2 years in general within the studied districts (Table 3). Average household head age in the five districts had significant difference at 5\% significance level. The mean age of total sample of respondents was 41.2 years which indicated that horticultural crops producing farmers in the districts have good working mean age. This is also in line with Biruk Seifu (2013) which showed that if the majority of the household are under active age group, there is perception to new technologies and crops productivity.

Education level of the household head in the five districts has significant variation at 5\% significance level. And their educational level varied from illiterate to $12^{\text {th }}$ grade completion with an average of grade $6^{\text {th }}$ level educated households (Table 3 ). The results indicated that less literate households participated in horticultural crops producing as compared to others findings even though the literacy rate helped them to produce and supply more crop product and quality. Also Astewel (2010) found that if paddy producer gets educated, the production and market supply become increases as well.

The available data indicated that the family size of the respondents was between 2.00 and 20.00 with an average of 6.00 family sizes within the studied five districts. The result showed that there was a significance difference in horticultural crops producing family size in the five districts at 5\% significance level. Biruhalem (2010) indicated that larger families with their greater supply of labor are expected to adopt a technology than the smaller family size. Potato production and selling to the market requires higher labor with households having larger family size were likely to produce and sell more of potato than those who have lower family size.

Table3. Demographic and socioeconomic characteristics of sample respondents (categorical variables)

\begin{tabular}{|c|c|c|c|c|c|}
\hline & $\mathrm{N}$ & Minimum & Maximum & Mean & Std. Deviation \\
\hline Age of respondent & 160 & 22.00 & 77.00 & 41.2125 & 10.73019 \\
\hline Education level of respondent & 160 & 0.00 & 12.00 & 6.0250 & 3.19778 \\
\hline Family size & 160 & 2.00 & 20.00 & 6.3063 & 2.60623 \\
\hline Valid N (listwise) & 160 & & & & \\
\hline
\end{tabular}

The marital status and sex of respondents also significantly varied between the studied districts of Arsi zone and these factors significantly influenced the crop production. The results of the study indicated that from the total respondents, $92.5 \%$ were male headed households and only $7.5 \%$ were female headed households in the five districts (Table 4). In case of marital status, $92.5 \%$ of the respondents were married, only $3.12 \%, 0.63 \%$ and $3.75 \%$ of the respondents were unmarried, divorced and widowed respectively in the studied five districts (Table 4).

Table4. Demographic characteristics of sample respondents (categorical variables)

\begin{tabular}{|c|c|c|c|c|c|c|c|c|c|c|c|c|c|}
\hline & \multicolumn{10}{|c|}{ District } & \multicolumn{2}{|c|}{ Total } \\
\hline & & \multicolumn{2}{|c|}{ Hetosa } & \multicolumn{2}{|c|}{ Z/Dugda } & \multicolumn{2}{|c|}{ D/Tijo } & \multicolumn{2}{|c|}{ Tiyo } & \multicolumn{2}{|c|}{ L/Bilbilo } & \multirow[b]{2}{*}{ No } & \multirow[b]{2}{*}{$\%$} \\
\hline & & No & $\%$ & No & $\%$ & No & $\%$ & No & $\%$ & No & $\%$ & & \\
\hline \multirow{4}{*}{$\begin{array}{c}\text { Marital } \\
\text { status }\end{array}$} & Married & 15 & 10.1 & 24 & 16.2 & 38 & 25.7 & 39 & 26.4 & 32 & 21.6 & 148 & 92.5 \\
\hline & Unmarried & 0 & 0.0 & 0 & 0.0 & 2 & 40.0 & 1 & 20.0 & 2 & 40.0 & 5 & 3.12 \\
\hline & Divorced & 0 & 0.0 & 0 & 0.0 & 0 & 0.0 & 0 & 0.0 & 1 & 100.0 & 1 & 0.63 \\
\hline & Widowed & 1 & 16.7 & 5 & 83.3 & 0 & 0.0 & 0 & 0.0 & 0 & 0.0 & 6 & 3.75 \\
\hline \multirow{2}{*}{$\begin{array}{c}\text { Sex of } \\
\text { respondent }\end{array}$} & Male & 14 & 9.5 & 27 & 18.2 & 35 & 23.6 & 38 & 25.7 & 34 & 23.0 & 148 & 92.5 \\
\hline & Female & 2 & 16.7 & 2 & 16.7 & 5 & 41.7 & 2 & 16.7 & 1 & 8.3 & 12 & 7.5 \\
\hline
\end{tabular}




\subsubsection{Horticulture Crops Production and Supply to Market}

The total amount of horticultural crops produced for consumption and supplied to the market by the producers was differed in terms of quantity. On average, producers of horticultural crops produced less $25 \%$ of their total production for home consumption as $84.38 \%$ of the respondents were replied and from $50-100 \%$ of horticultural commodities production was for selling purposes according to $93 \%$ of the respondents in the study districts (Table 5). Only $2.50 \%$ and $6.87 \%$ of the producers of the studied farmers produced horticultural crops for home consumption at large and selling at small amount in the districts, respectively before production season 2017. Farmers in the five districts supplied the largest proportion of horticultural crops produced to the market and sold. This showed that horticultural crops were produced mainly for the market in order to generate income from farm. The study indicated that producers of the crop in Hetosa and D/Tijo supplied to the market more than those in other studied districts (Table 5).

Table5. Average yield of horticultural crops production for both consumption and marketing in the five districts

\begin{tabular}{|c|c|c|c|c|c|c|c|c|c|c|c|c|c|}
\hline & \multicolumn{10}{|c|}{ District } & \multicolumn{2}{|c|}{ Total } \\
\hline & & \multicolumn{2}{|c|}{ Hetosa } & \multicolumn{2}{|c|}{ Z/Dugda } & \multicolumn{2}{|c|}{ D/Tijo } & \multicolumn{2}{|c|}{ Tiyo } & \multicolumn{2}{|c|}{ L/Bilbilo } & & \\
\hline & & No & $\%$ & No & $\%$ & No & $\%$ & No & $\%$ & No & $\%$ & No & $\%$ \\
\hline \multirow{4}{*}{$\begin{array}{l}\text { How much of } \\
\text { the produce is } \\
\text { for home } \\
\text { consumption }\end{array}$} & $0-25 \%$ & 15 & 11.1 & 24 & 17.8 & 39 & 28.9 & 33 & 24.4 & 24 & 17.8 & 135 & 84.38 \\
\hline & $25 \%-50 \%$ & 1 & 4.8 & 5 & 23.8 & 1 & 4.8 & 6 & 28.6 & 8 & 38.1 & 21 & 13.12 \\
\hline & $50 \%-75 \%$ & 0 & 0.0 & 0 & 0.0 & 0 & 0.0 & 0 & 0.0 & 3 & 100 & 3 & 1.88 \\
\hline & $100 \%$ & 0 & 0.0 & 0 & 0.0 & 0 & 0.0 & 1 & 100.0 & 0 & 0.0 & 1 & 0.62 \\
\hline \multirow{4}{*}{$\begin{array}{c}\text { How much of } \\
\text { produce for } \\
\text { sell }\end{array}$} & $0-25 \%$ & 0 & 0.0 & 0 & 0.0 & 0 & 0.0 & 1 & 50.0 & 1 & 50.0 & 2 & 1.25 \\
\hline & $25-50 \%$ & 0 & 0.0 & 2 & 22.2 & 0 & 0.0 & 4 & 44.4 & 3 & 33.3 & 9 & 5.62 \\
\hline & $50-75 \%$ & 12 & 8.9 & 22 & 16.3 & 35 & 25.9 & 35 & 25.9 & 31 & 23.0 & 135 & 84.38 \\
\hline & $100 \%$ & 4 & 28.6 & 5 & 35.7 & 5 & 35.7 & 0 & 0.0 & 0 & 0.0 & 14 & 8.75 \\
\hline
\end{tabular}

\subsubsection{Different Inputs Used for Horticulture Crops Production}

The amounts of fertilizer input used by farmers were showed variations which ranges from 0 to 350,000 $\mathrm{kg}$ per year for organic fertilizer and from 0 to $1400 \mathrm{~kg}$ per year for inorganic fertilizer in the five studied districts with an average of 6203 and $301 \mathrm{~kg}$ per year respectively (Tables 10). The rates of both inorganic and organic fertilizers usage were more in Digalu-Tijo and Tiyo districts than in other districts; this might be due to the farmers in the both districts are known animal rearing and thus additional use of organic fertilizer to minimize the inorganic fertilizers cost (Table 6).

Table6. Amounts of organic and inorganic fertilizers applied by farmers per year for horticultural crops production (Descriptive Statistics)

\begin{tabular}{|c|c|c|c|c|c|}
\hline & $\mathrm{N}$ & Minimum & Maximum & Mean & Std. Deviation \\
\hline $\begin{array}{c}\text { Amount of organic fertilizer applied in kg } \\
\text { per year }\end{array}$ & 160 & 0.00 & 350000.00 & 6202.97 & 29338.81 \\
\hline $\begin{array}{c}\text { Amount of inorganic fertilizer applied in kg } \\
\text { per year }\end{array}$ & 160 & 0.00 & 1400.00 & 301.25 & 207.17 \\
\hline Valid N (list wise) & 160 & & & & \\
\hline
\end{tabular}

The main types of seed used in the study areas were: improved, local and both seeds types. Out of 160 sample respondents in the five districts, 89 (55.63\%) households used local varieties of horticultural crops for production and 69(43.13\%) households used improved varieties of horticultural crops; but only $2(1.25 \%)$ used both improved and local varieties of horticultural crops in the five districts of the study (Table 7).

Also the types of fertilizers used by farmers to improve their horticultural crops in the study areas significantly varied across the studied districts and types of fertilizers utilized by the responded communities. Majority of the respondents used both inorganic and organic fertilizers (66.88\%) for their horticultural crops production and $30.62 \%$ of them utilized only inorganic fertilizer which indicated that both types of fertilizers utilization possibility for horticultural crops production and basing also on utilization if inorganic fertilizer as it advanced by $94 \%$ as compared to organic fertilizer alone used by respondents (Table 7). Also more than $99 \%$ of the respondents used insecticides for the management of horticultural crops in all the studied districts except one respondent not used in Tiyo district. 
Table7. Rates of inputs utilization per ha for horticulture crops production in 2016/17 in $\mathrm{kg}$

\begin{tabular}{|c|c|c|c|c|c|c|c|c|c|c|c|c|c|}
\hline & \multicolumn{10}{|c|}{ District } & \multicolumn{2}{|c|}{ Total } \\
\hline & & \multicolumn{2}{|c|}{ Hetosa } & \multicolumn{2}{|c|}{ Ziway-Dugda } & \multicolumn{2}{|c|}{ Digalu -Tijo } & \multicolumn{2}{|c|}{ Tivo } & \multicolumn{2}{|c|}{$\begin{array}{l}\text { Lemu - } \\
\text { Bilbilo }\end{array}$} & \multirow[b]{2}{*}{ No } & \multirow[b]{2}{*}{ \% } \\
\hline & & No & $\%$ & No & $\%$ & No & $\%$ & No & $\%$ & No & $\%$ & & \\
\hline \multirow{3}{*}{$\begin{array}{c}\text { Type of } \\
\text { seed used }\end{array}$} & Improved & 5 & 7.2 & 11 & 15.9 & 13 & 18.8 & 25 & 36.2 & 15 & 21.7 & 69 & 43.13 \\
\hline & Local & 11 & 12.4 & 18 & 20.2 & 27 & 30.3 & 15 & 16.9 & 18 & 20. & 89 & 55.63 \\
\hline & Both & 0 & 0.0 & 0 & 0.0 & 0 & 0.0 & 0 & 0.0 & 2 & 100.0 & 2 & 1.25 \\
\hline \multirow{4}{*}{$\begin{array}{l}\text { Type of } \\
\text { fertilizer } \\
\text { used }\end{array}$} & Organ & 0 & 0.0 & 0 & 0.0 & 1 & 33.3 & 2 & 66.7 & 0 & 0.0 & 3 & 1.88 \\
\hline & Inorga & 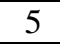 & 10.2 & 13 & .5 & 12 & 24.5 & 8 & 16.3 & 11 & 22 & 49 & 30.62 \\
\hline & & 10 & 9.3 & 16 & 0 & 27 & 25.2 & 30 & 28.0 & 24 & 22.4 & 107 & 66.88 \\
\hline & Not & 1 & 10 & 0 & 0.0 & 0 & 0.0 & 0 & 0.0 & 0 & 0 & 1 & 0.62 \\
\hline \multirow{2}{*}{\begin{tabular}{|c|} 
Using of \\
insecticides
\end{tabular}} & & 0 & 0 & 0 & 0.0 & 0 & 0.0 & 1 & 100.0 & 0 & 0.1 & 1 & 0.62 \\
\hline & Yes & 16 & 10.0 & 29 & 18.24 & 40 & 25.16 & 39 & 24.53 & 35 & 22.0 & 159 & 99.38 \\
\hline
\end{tabular}

The main sources of seed supply in the study areas were: market, agricultural extension office, own source and non-governmental organizations (NGO) input suppliers in decreasing order. Out of 160 sample respondents in the five districts, $99(61.88 \%)$ households used improved varieties of horticultural crops from market during planting, 31(19.38\%) from agricultural extension, 17(10.62\%) from their own source and only 13(8.12\%) from non-governmental organizations for the five districts of the study (Table 8 ). The other inputs sources also significantly varied across the studied districts and sources which includes inorganic fertilizers, pesticides and farm implements. About $43.75 \%$ and $36.25 \%$ of the farmers obtained improved inputs from primary cooperatives and local markets in total five districts, respectively. Out of 160 respondents who used improved inputs, $16.88 \%$ of them obtained the modern inputs from district government offices and only fem of them (3.12\%) obtained from farmers in their areas. However, horticultural crops producing farmers in the study areas did not access any of the modern inputs from NGO, research and university institutions except improved seed from NGO (Table 8). Also Biruhalem (2011) revealed that primary cooperatives are the most important source of rice seed. Some farmers are also using organic fertilizers such as manure and compost. Also the sources of inputs were varied between studied districts with highest from market and higher in Hetosa (75\%) and Lemu-Bilbilo (74\%) and lowest in Tiyo district (50\%).

Table8. Source of inputs used in horticultural crops production in five districts of studied areas

\begin{tabular}{|c|c|c|c|c|c|c|c|c|c|c|c|c|c|}
\hline & \multicolumn{10}{|c|}{ District } & \multicolumn{2}{|c|}{ Total } \\
\hline & & \multicolumn{2}{|c|}{ Hetosa } & \multicolumn{2}{|c|}{ Z/Dugda } & \multicolumn{2}{|c|}{ D/Tijo } & \multicolumn{2}{|c|}{ Tiyo } & \multicolumn{2}{|c|}{ L/Bilbilo } & \multirow[b]{2}{*}{ No } & \multirow[b]{2}{*}{70} \\
\hline & & No & $\%$ & No & $\%$ & No & $\%$ & No & $\%$ & No & $\%$ & & \\
\hline \multirow[t]{4}{*}{\begin{tabular}{|c|}
$\begin{array}{c}\text { Source of } \\
\text { seed }\end{array}$ \\
\end{tabular}} & $\begin{array}{l}\text { Agr/extension } \\
\text { office }\end{array}$ & 1 & 3.2 & 7 & 22.6 & 5 & 16.1 & 14 & 45.2 & 4 & 12.9 & 31 & 19.38 \\
\hline & Market & 12 & 12.1 & 19 & 19.2 & 22 & 22.2 & 20 & 20.2 & 26 & 26.3 & 99 & 61.88 \\
\hline & Own source & 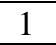 & 5.9 & 0 & 0.0 & 5 & 29.4 & 6 & 35.3 & 5 & 29.4 & 17 & 10.62 \\
\hline & NGO & 2 & 15.4 & 3 & 23.1 & 8 & 1.5 & 0 & 0.0 & 0 & 0.0 & 13 & 8.12 \\
\hline \multirow{7}{*}{$\begin{array}{c}\text { Source of } \\
\text { other } \\
\text { inputs }\end{array}$} & District off & 0 & 0.0 & 2 & 7.4 & 4 & 14.8 & 8 & 25.9 & 13 & 51.9 & 27 & 16.88 \\
\hline & Local market & 5 & 8.6 & 15 & 25.9 & 14 & 24.1 & 14 & 24.1 & 10 & 17.2 & 58 & 36.25 \\
\hline & Cooperatives & 11 & 15.7 & 9 & 12.9 & 21 & 30.0 & 18 & 25.7 & 11 & 15.7 & 70 & 43.75 \\
\hline & NGOs & 2 & 0.0 & 0 & 0.0 & 0 & 0.0 & 0 & 0.0 & 0 & 0.0 & 0 & 0.0 \\
\hline & Research c & 0 & 0.0 & 0 & 0.0 & 0 & 0.0 & 0 & 0.0 & 0 & 0.0 & 0 & 0.0 \\
\hline & Arsi univ & 0 & 0.0 & U & 0.0 & 0 & 0.0 & 0 & 0.0 & 0 & 0.0 & 0 & 0.0 \\
\hline & mers & U & 0.0 & 3 & 60.0 & 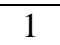 & 20.0 & 0 & 0.0 & 1 & 20.0 & 5 & 3.12 \\
\hline
\end{tabular}

Note. $N^{o}=$ sample size and $\%=$ percentage of house hold respondents; Source: from the study result of 2016/17

\subsubsection{Types of Services snd its Sources}

Finance is the most important element in agriculture, specifically in horticultural crops production which is used to cover the production expenses ranging from land cleaning to production to marketing. The study showed that from the total respondents, $131(81.88 \%)$ have no credit access and only $29(18.12 \%)$ have the credit access in the studied districts. More farmers $(37.5 \%)$ had access to credit from Hetosa district than other districts (Table 9). Biruk (2013) revealed that access to credit service helps the farmers to purchase agricultural inputs such as fertilizers, improved seeds and oxen, and which in turn increases production and contributes to food security. According to Kindie (2007), credit access improves the financial capacity of farmers to buy modern inputs, thereby increasing production and market supply of sesame. 
The main sources of training horticultural crops were Development Agents and district experts in the districts. Agriculture development office in the districts provided agricultural extension services to the respective farmers through DA workers. From the total sampled horticultural crops producers, $60.62 \%$ have been taken training services and $39.38 \%$ had no training on horticultural crops production in the districts (Table 9). Farmers responded that they are getting some times advisory service and market information on seed production, crop management and marketing in the districts.

Problem faced on advisory/extension service is that there was no specialized advisory service designed only for horticultural crops producers. The extension services were offered for different kinds of vegetable product. More importantly, the study results indicated that $56.25 \%$ of the respondents accessed in horticultural extension services and $43.75 \%$ of did not access extension services on horticultural crops that were organized by districts and other officers (Table 9). Regarding to market information access, among the total sampled respondents, $62.50 \%$ of them responded that as they have been getting market information accesses in horticultural crops production and $37.50 \%$ of them had no market information in the studied districts. This large number of the respondents in accessing market information might be due to availability of mobile phone which enhances their timely communication with traders.

In both study areas, micro finance, cooperatives and traders have been identified as a potential source for credit both in material and on cash basis. Majority of the farmers $(53.75 \%)$ in all five districts had interest to borrow money for improvement of their horticultural crops productivity. Only $46.25 \%$ of them showed negative response to borrow money from the different finance institutions which might be due to fear of its interest payments (Table 9). With regard to interest to borrow money for horticultural crops production, more number of farmers from Z/Dugda, D/Tijo and Tiyo districts responded to had interest to borrow money for their production and equal number of farmers from Hetosa; but more number of farmers had no interest to borrow for their horticultural crops production in L/Bilbilo as compared to other districts (Table 9).

Table9. Access to different services by sample respondents within five districts

\begin{tabular}{|c|c|c|c|c|c|c|c|c|c|c|c|c|c|}
\hline & \multicolumn{10}{|c|}{ District } & \multicolumn{2}{|c|}{ Total } \\
\hline & & \multicolumn{2}{|c|}{ Hetosa } & \multicolumn{2}{|c|}{ Z/Dugda } & \multicolumn{2}{|c|}{ D/Tijo } & \multicolumn{2}{|c|}{ Tiyo } & \multicolumn{2}{|c|}{ L/Bilbilo } & \multirow[b]{2}{*}{ No } & \multirow[b]{2}{*}{$\%$} \\
\hline & & No & $\%$ & No & $\%$ & No & $\%$ & No & $\%$ & No & $\%$ & & \\
\hline \multirow{2}{*}{$\begin{array}{l}\text { Credit access during last } \\
\text { production seasons }\end{array}$} & Yes & 6 & 23.1 & 6 & 11.5 & 5 & 19.2 & 10 & 38.5 & 2 & 7.7 & 29 & 18.12 \\
\hline & No & 10 & 2.6 & 23 & 14.0 & 35 & 28.9 & 30 & 25.4 & 33 & 28.9 & 131 & 81.88 \\
\hline \multirow{2}{*}{$\begin{array}{c}\text { Extension services access } \\
\text { to horticultural cultural } \\
\text { practices }\end{array}$} & Yes & 6 & 6.7 & 14 & 15.6 & 19 & 21.1 & 29 & 32.2 & 22 & 24.4 & 90 & 56.25 \\
\hline & No & 10 & 14.3 & 15 & 21.4 & 21 & 30.0 & 11 & 15.7 & 13 & 18.6 & 70 & 43.75 \\
\hline \multirow{2}{*}{$\begin{array}{c}\text { Market information } \\
\text { access }\end{array}$} & Yes & 6 & 6.1 & 16 & 16.2 & 31 & 31.3 & 25 & 25.3 & 22 & 21.2 & 100 & 62.50 \\
\hline & No & 10 & 17.3 & 13 & 23.1 & 9 & 15.4 & 15 & 23.1 & 13 & 21.2 & 60 & 37.50 \\
\hline \multirow{2}{*}{$\begin{array}{c}\text { Interest to borrow money } \\
\text { for horticultural crops } \\
\text { production }\end{array}$} & Yes & 8 & 9.3 & 17 & 19.8 & 26 & 30.2 & 24 & 27.9 & 11 & 12.8 & 86 & 53.75 \\
\hline & No & 8 & 10.8 & 12 & 16.2 & 14 & 18.9 & 16 & 21.6 & 24 & 32.4 & 74 & 46.25 \\
\hline \multirow{2}{*}{$\begin{array}{c}\text { Training access on } \\
\text { agriculture/ horticulture } \\
\text { production }\end{array}$} & Yes & 14 & 14.4 & 15 & 15.5 & 19 & 19.6 & 22 & 22.7 & 27 & 27.8 & 97 & 60.62 \\
\hline & No & 2 & 3.2 & 14 & 22.2 & 21 & 33.3 & 18 & 28.6 & 8 & 12.7 & 63 & 39.38 \\
\hline
\end{tabular}

Note. No=sample size, ** is significant at 5\% significance level; Source: from the study result of 2016/17

\subsubsection{Location and Infrastructure}

Different infrastructures also significantly influenced the production of horticultural crops in the studied areas. Means of transportation, types of roads and distances from main road and market, family size, amount of land holding, number of livestock they have, production rate and inputs utilization also affects the quantity and quality of horticultural crops product produced and supplied to the market. Hence, the distance from nearest market and main road varies from 1 to $33 \mathrm{~km}$ and 1 to $37 \mathrm{~km}$ with an average of $9.86 \mathrm{~km}$ respectively (Table 10). Which indicated that good transportation systems required to transport the perishable horticultural crops immediately after harvested otherwise they have to be consumed as there is no a better storage facilities in the local districts. Also there are traders who usually collects horticultural crops product from producers` farms and from the village market to resell it to other value chain actors such as wholesalers and retailers. This account majority of trading of horticultural crops where they move the product from the area it was produced to the area where 
wholesalers and retailers exist. Usually, traders have more storage facilities as compared to producers that can add values to the horticultural crops product which includes assembling, cleaning, sorting, grading, transporting, storage and selling to the markets.

The farm land holding capacity of the households was ranged from zero to 10 ha with an average of 2 ha, total number of livestock owner varied from zero to 33 with an average of 10 . The producers also have varied number of family size which ranged from 2 to 20 with an average family size of 6 and amount of inorganic fertilizer input from none to $1400 \mathrm{~kg} / \mathrm{ha}$ (Table 10). These indicated that they have used different resources for their horticulture crops productivity improvement and supplying to market immediately after harvested. Also the rate of production varied from one to four times per year with an average of production twice per year which indicated that the farmers were depend more on rain-fed and fall seasons from march to September even though some of producers using irrigation for some horticultural crops production.

Table10. Household respondents distance from market center and main road and resources holding (Descriptive Statistics)

\begin{tabular}{|c|c|c|c|c|c|}
\hline & $\mathbf{N}$ & Minimum & Maximum & Mean & Std. Deviation \\
\hline Distance from the nearest market in km & 160 & 1.00 & 33.00 & 9.8562 & 8.07110 \\
\hline Distance from main road in km & 160 & 1.00 & 37.00 & 9.8594 & 9.21377 \\
\hline Age of respondent & 160 & 22.00 & 77.00 & 41.2125 & 10.73019 \\
\hline Education level of respondent & 160 & 0.00 & 12.00 & 6.0250 & 3.19778 \\
\hline Number of production per year & 160 & 1.00 & 4.00 & 2.1000 & .52844 \\
\hline Family size & 160 & 2.00 & 20.00 & 6.3063 & 2.60623 \\
\hline Total number of livestock & 160 & 0.00 & 33.00 & 9.9875 & 6.02405 \\
\hline Total farm land in hectare & 160 & 0.00 & 10.00 & 1.9969 & 1.53573 \\
\hline Amount of inorganic fertilizer (kg/year) & 160 & 0.00 & 1400.00 & 301.25 & 207.17401 \\
\hline Valid N (listwise) & 160 & & & & \\
\hline
\end{tabular}

Note. No=sample size, *** is significant at 1\% significance level; Source: from the study result of 2016/17

\subsection{Constraints and Opportunities in Horticulture Crops Production}

A number of constraints and opportunities for further technological, institutional and organizational innovation for upgrading the production of horticultural crops in the study areas/districts were identified along the main production and supply. In this subsection, the major constraints and opportunities are briefly discussed.

\subsubsection{Production constraints}

The major factors that reduces the production level in the study area includes: Fertilizer shortage, lack of pesticides, insects, diseases, weeds and seed shortage. The major problems faced by the producers (Table 14).

\section{Natural factors}

These natural factors are beyond the control of the farmers which mainly includes rainfall fluctuation. The majority of the respondents in the studied districts were replied that they depend on by rain fall due to unavailability of irrigation schemes. The major production constraint was water shortage or erratic rainfall (Tewodros et al., 2014). This indicated that utilization of irrigation scheme by farmers in the study areas were limited. In Ethiopia, the main production season for horticulture crops, at altitudes higher than about 2,500 masl is June to September (Anton Haverkort et al., 2012). This in turn resulted in low production and supply of the produce into the market, and also caused fluctuation in volume of productivity in the respective study areas.

\section{Limited Access to Supply of Agricultural Inputs}

Some of the type of modern agricultural inputs that the farmers faced in the districts include: Fertilizer shortage, lack of pesticides and improved seed shortage. Among the sample respondents, $66.3 \%, 71.3 \%$, $72.5 \%$ and $70.6 \%$ in the five districts replied that they have constrained by lack of money to invest, limited knowhow and skill, lack of market and transportation and storage facilities respectively (Table 11). This in turn have a negative impact on the application of modern agricultural inputs. Other factors includes: seed supply shortage, delay in supply of inputs, high input price and others. 
In general focus group discussion and key informant indicated that limited access to supply of agricultural inputs problems' were caused mainly due to the absence of horticultural seed multiplying and distributing agency and inappropriate delivery mechanisms of inputs. This finding is supported by Abraham (2013) who found that farmers were small-scale and unorganized in Habro and Kombolcha districts in Oromia Region. He suggested policy intervention to strengthen farmers' cooperative and encourage collective action of farmers to lower transaction costs to access modern input technologies through their organization that is essential in increasing the production and productivity of horticulture crops. Additionally the majority of the respondents also revealed that there were the problems of shortage of supply, delay of supply and high price in delivering inorganic fertilizer and chemicals in the study areas.

Table11. Constraints hindering farmers to increase their horticultural crops productions

\begin{tabular}{|c|c|c|c|c|c|c|}
\hline & Type of Constraints & & Frequency & Percent & $\begin{array}{c}\text { Valid } \\
\text { Percent }\end{array}$ & Cumulative Percent \\
\hline \multirow[t]{3}{*}{1} & \multirow{3}{*}{$\begin{array}{c}\text { Lack of money to invest is } \\
\text { encountered }\end{array}$} & Yes & 106 & 66.2 & 66.2 & 66.2 \\
\hline & & No & 54 & 33.8 & 33.8 & 100.0 \\
\hline & & Total & 160 & 100.0 & 100.0 & \\
\hline \multirow[t]{3}{*}{2} & \multirow{3}{*}{$\begin{array}{l}\text { Limited knowhow and } \\
\text { skill }\end{array}$} & Yes & 114 & 71.2 & 71.2 & 71.2 \\
\hline & & No & 46 & 28.8 & 28.8 & 100.0 \\
\hline & & Total & 160 & 100.0 & 100.0 & \\
\hline \multirow[t]{3}{*}{3} & \multirow[t]{3}{*}{ Lack of market } & Yes & 116 & 72.5 & 72.5 & 72.5 \\
\hline & & No & 44 & 27.5 & 27.5 & 100.0 \\
\hline & & Total & 160 & 100.0 & 100.0 & \\
\hline \multirow[t]{3}{*}{4} & \multirow{3}{*}{$\begin{array}{c}\text { Transportation and storage } \\
\text { house problems }\end{array}$} & Yes & 113 & 70.6 & 70.6 & 70.6 \\
\hline & & No & 47 & 29.4 & 29.4 & 100.0 \\
\hline & & Total & 160 & 100.0 & 100.0 & \\
\hline
\end{tabular}

\section{Limited Knowhow and Skill}

The study result showed that $71.2 \%$ of the sample household heads mentioned that there were the problems of limited knowhow and skill of farmers that affected the increment of production and productivity of the districts (Table 11). This is mainly related with limited extension and advice services in the study areas (Table 11). Only 28.8 of the respondents had knowhow and skill on their production of horticultural crops. Also this finding is supported by the result of Ayelech (2011) who found that if fruit producer gets extension their knowhow and skill increase; as a result the production and amount of marketable supply of fruits is increasing in Gomma district.

\section{Limited Access to Credit}

The study result showed that only $66.2 \%$ of respondents had received credit/money access (Table 11 ). In general focus group discussion and key informant indicated that huge bureaucracy, limited supply of credit and high cost of credit were the causes for limited access to credit and inappropriate delivery mechanisms of the credits to the community. However, about $33.8 \%$ of the households responded that they have got money to invest on horticultural crops like potato, onion, and shallots. Table 12 summarized that $44.4 \%, 43.1 \%, 38.8 \%$ and $20.6 \%$ of sampled household heads identified that huge bureaucracy, high cost of credit/interest, limited supply of credit and limited access to transport were the causes for limited access to money to invest more on their horticultural crops, respectively.

Table12. Constraints of accessing credit service in study areas

\begin{tabular}{|c|c|c|c|c|c|c|}
\hline & Prioritized Constraints & & Frequency & Percent & Valid Percent & Cumulative Percent \\
\hline \multirow[t]{3}{*}{$\mathbf{1}^{\text {st }}$} & \multirow[t]{3}{*}{ Huge bureaucracy } & Yes & 71 & 44.4 & 44.4 & 44.4 \\
\hline & & No & 89 & 55.6 & 55.6 & 100.0 \\
\hline & & Total & 160 & 100.0 & 100.0 & \\
\hline \multirow[t]{3}{*}{$2^{\text {nd }}$} & \multirow[t]{3}{*}{ High cost of credit } & Yes & 69 & 43.1 & 43.1 & 43.1 \\
\hline & & No & 91 & 56.9 & 56.9 & 100.0 \\
\hline & & Total & 160 & 100.0 & 100.0 & \\
\hline \multirow[t]{3}{*}{$3^{\text {rd }}$} & \multirow[t]{3}{*}{ Limited supply of credit } & Yes & 62 & 38.8 & 38.8 & 38.8 \\
\hline & & No & 98 & 61.3 & 61.3 & 100.0 \\
\hline & & Total & 160 & 100.0 & 100.0 & \\
\hline \multirow[t]{3}{*}{$4^{\text {th }}$} & \multirow{3}{*}{$\begin{array}{l}\text { Limited access to } \\
\text { transport }\end{array}$} & Yes & 33 & 20.6 & 20.6 & 20.6 \\
\hline & & No & 127 & 79.4 & 79.4 & 100.0 \\
\hline & & Total & 160 & 100.0 & 100.0 & \\
\hline
\end{tabular}


The result of focus group discussion identified that due to absence of appropriate post harvest handling practices, lack of storage facilities in the study areas and perishability nature of the horticultural crops and management techniques of the produce across the value chains. The discussion result showed that majority of produce losses' starting from harvesting up to consumption of the product in the study areas. They indicated that losses were more than the findings of USAID (2013) which reported that the proportion post-harvest loss of onion in Ethiopia was about 10.7\%. This might be due to lack of proper handling and insufficient value added activities performed along the horticultural crops chain and it was highest at wholesalers' stage.

\subsubsection{Marketing Constraints}

The marketing problems mentioned by farmers include low selling price (especially during on-season), high seeds price, interference of brokers in the market and using backward transport systems. The majority of horticultural crops producers responded that there were marketing problems in the study areas (Table 13). The study result showed that $78.8 \%, 75.6 \%, 70.6 \%$ and $68.1 \%$ of the respondents identified that low price of produce at harvesting time, perishability nature of the produce, lack of storage facilities, and poor linkage with different stakeholders as major marketing constraints in the study areas, respectively. The study result showed that there was lack of coordination among producers that help them to increase their bargaining power and participating in horticultural crops marketing activities in organized way. There were no any horticultural crops marketing institution that was linked with producers to safeguard farmer's interest and rights over their horticultural crops marketable produces. The result of this study is in line with Bezabih (2008) who identified lack of coordination among producers was one of the problems of the horticulture value chain in Kombolcha district of Eastern Oromia.

Also farmers in the study areas are often poorly linked to markets and do not adequately access market information. Often middlemen do make much higher marketing margins than the producers, limiting the motivation of farmers to expand horticultural crops production. In contrary, the farmers were incurring high costs for inputs such as fertilizers and agrochemicals. Lack of market, lack of market information, transport services and long distances of market place were also raised by producers as bottlenecks of horticultural crops production and marketing as of $56.3 \%, 53.8 \%, 51.3 \%$ and $38.8 \%$ of the respondents responded that they had marketing problems in the studied districts, respectively (Table 13). This might be due to lack of integration between different actors in the horticultural crops production and marketing activities.

Table13. Constraints of horticultural crops marketing in study areas

\begin{tabular}{|c|c|c|c|c|c|c|}
\hline & $\begin{array}{l}\text { Prioritized } \\
\text { Constraints }\end{array}$ & & Frequency & Percent & Valid Percent & Cumulative Percent \\
\hline \multirow[t]{3}{*}{$1^{\text {st }}$} & \multirow[t]{3}{*}{ Low price of products } & Yes & 126 & 78.8 & 78.8 & 78.8 \\
\hline & & No & 34 & 21.3 & 21.3 & 100.0 \\
\hline & & Total & 160 & 100.0 & 100.0 & \\
\hline \multirow[t]{3}{*}{$2^{\text {nd }}$} & \multirow[t]{3}{*}{ Perishability } & Yes & 121 & 75.6 & 75.6 & 75.6 \\
\hline & & No & 39 & 24.4 & 24.4 & 100.0 \\
\hline & & Total & 160 & 100.0 & 100.0 & \\
\hline \multirow[t]{3}{*}{$3^{\text {rd }}$} & \multirow{3}{*}{$\begin{array}{c}\text { Lack of storage } \\
\text { facilities }\end{array}$} & Yes & 113 & 70.6 & 70.6 & 70.6 \\
\hline & & No & 47 & 29.4 & 29.4 & 100.0 \\
\hline & & Total & 160 & 100.0 & 100.0 & \\
\hline \multirow[t]{3}{*}{$4^{\text {th }}$} & \multirow{3}{*}{$\begin{array}{l}\text { Poor linkage with } \mathrm{d} / \mathrm{t} \\
\text { stakeholders }\end{array}$} & Yes & 109 & 68.1 & 68.1 & 68.1 \\
\hline & & No & 51 & 31.9 & 31.9 & 100.0 \\
\hline & & Total & 160 & 100.0 & 100.0 & \\
\hline \multirow[t]{3}{*}{$5^{\text {th }}$} & \multirow[t]{3}{*}{ Lack of market } & Yes & 90 & 56.3 & 56.3 & 56.3 \\
\hline & & No & 70 & 43.8 & 43.8 & 100.0 \\
\hline & & Total & 160 & 100.0 & 100.0 & \\
\hline \multirow[t]{3}{*}{$6^{\text {th }}$} & \multirow{3}{*}{$\begin{array}{l}\text { Lack of market } \\
\text { information }\end{array}$} & Yes & 86 & 53.8 & 53.8 & 53.8 \\
\hline & & No & 74 & 46.3 & 46.3 & 100.0 \\
\hline & & Total & 160 & 100.0 & 100.0 & \\
\hline \multirow[t]{3}{*}{$7^{\text {th }}$} & \multirow{3}{*}{$\begin{array}{c}\text { Lack of transport } \\
\text { services }\end{array}$} & Yes & 82 & 51.3 & 51.3 & 51.3 \\
\hline & & No & 78 & 48.8 & 48.8 & 100.0 \\
\hline & & Total & 160 & 100.0 & 100.0 & \\
\hline \multirow[t]{3}{*}{$8^{\text {th }}$} & \multirow{3}{*}{$\begin{array}{l}\text { Long distance of } \\
\text { market place }\end{array}$} & Yes & 62 & 38.8 & 38.8 & 38.8 \\
\hline & & No & 98 & 61.3 & 61.3 & 100.0 \\
\hline & & Total & 160 & 100.0 & 100.0 & \\
\hline
\end{tabular}




\subsubsection{Production Opportunities}

The studied districts showed that there are production potentials in the districts like suitability to produce not only horticultural products but also other market oriented commodities of cereal, pulses and/or animal production; and the favorable agro-ecology of the area help to produce horticulture crops is a good opportunity to boost production in the area. On top of this, relatively fertile arable land and abundant underground water potential are some of the opportunities available mentioned by producers. Even if it is not meet the demand of the producers, the availability of irrigation facilities in some districts like Lemu-Bilbilo, Eteya and Golga/katar as the opportunities for the producers to produces horticultural crops and generating income in short period.

Government agriculture policies and employment of development agents to give extension support for farmers at each kebeles are also taken as important production opportunities. The result of this study is in line with Bezabih and Hadera (2007) who identified that government policy and development strategy on agriculture provided opportunities for increased horticulture production in the Eastern Ethiopia. Furthermore, provision of infrastructure facilities like roads, telecommunication, power supply and presence of financial institutions are the infrastructural advantages that facilitate the production and marketing of horticultural crops in the study areas. Organizations and institutions such as Arsi university and Kulumsa research center, Agricultural growth project, Sustainable land management project, Arsi-Bale farmers union and cooperatives and other institutes in the area those have direct or indirect potential role in horticultural crops value chain development are also taken as opportunities. Also availability different private and organizational actors in the area can be utilized as an opportunity for directly and indirectly helping the local communities.

\subsubsection{Market Opportunities}

The study result of focal group discussion and key informant showed that availability of market demand throughout the year and growing number of buyers were the most important market opportunities of the study areas. This study result is supported by the finding of Bezabih and Hadera (2007) who identified the presence of demand for horticulture product played important role increasing market integration, and enabling livelihood diversification of the communities in the Eastern Ethiopia. The location proximity of the districts to Addis Ababa, Adama, and Asalla markets are also the opportunities that enhance level of commercialization in the study areas. The survey result of key informant replied that even if they aren't accessed equal for all farmers' infrastructural development such as telecommunication, electric power and road are also the other advantages to integrate and improve the marketing system in the zone and surrounding areas. Generally, these market opportunities are the most important factors to expand the production and marketing activities of horticultural crops produce in the study areas.

Table14. Summary of opportunities and constraints of horticulture crops productions

\begin{tabular}{|c|c|c|}
\hline Function & Opportunities & Constraints \\
\hline Input supply & $\begin{array}{c}\text { - Demand for quality seed, fertilizer } \\
\text { and farm implement tools } \\
\text { - Availability of fertilizer from } \\
\text { cooperatives }\end{array}$ & $\begin{array}{l}\text { - Poor quality, high price \& inadequate supply of } \\
\text { improved seed } \\
\text { - Un organized way of supply of inputs } \\
\text { required by producers }\end{array}$ \\
\hline Production & $\begin{array}{l}\text { - Favourable land and Climatic } \\
\text { condition for horticulture production } \\
\text { - Enabling policy environment and } \\
\text { Support from Government and Non } \\
\text { government organizations } \\
\text {-Proximity to market and demand for } \\
\text { produce }\end{array}$ & $\begin{array}{c}\text { - Disease, pest \& insect problems } \\
\cdot \text { Low productivity } \\
\text {-Limited irrigation facilities \& lack of sufficient } \\
\text { irrigation water } \\
\cdot \text { Perishability of produce } \\
\text { - Inadequate value added activities } \\
\text { - Low price for produce at peak harvesting time } \\
\text {-In adequate know how on agronomic practices }\end{array}$ \\
\hline \multirow[t]{3}{*}{ Marketing } & $\begin{array}{c}\text { - High market demand } \\
\text {-Infrastructure and proximity to } \\
\text { market center }\end{array}$ & $\begin{array}{c}\text { - Price fluctuation } \\
\text { - Lack of storage facility } \\
\text {-Competition with unlicensed traders }\end{array}$ \\
\hline & $\begin{array}{c}\text { - Market demand } \\
\text {-Availability of horticulture crops } \\
\text { throughout the year }\end{array}$ & $\begin{array}{c}\text { - Competition with unlicensed traders } \\
\text { - In adequate value added activities and loss of } \\
\text { produce }\end{array}$ \\
\hline & - Demand for consumption & $\begin{array}{c}\cdot \text { Inadequate value addition } \\
\text {-Loss of produce }\end{array}$ \\
\hline
\end{tabular}




\subsection{Core Intervention Areas for Further Development of Horticulture Crops Production}

The major constraints facing horticultural crops producers require a strategic intervention point which includes:

On the first phase, production system was mostly depended on rainfall; as a result there was no continuous supply of product due to fluctuation in the volume of market supply. Productivity and production of horticultural crops in the study areas were very low because of lack of organized and modern agricultural practices and other factors and it's another factor that needs an intervention point.

Secondly, even if the farmer were working hard and bear the risk of producing the horticultural crops, the major share of profit of the farmer gains was very low; the higher profit share was taken by the retailers and brokers as observed from focal group discussion. Also, the profit margin of the farmer had the chance to be increased because of the marketing cost of the farmer was low as compared to other actors. Hence, by adding a value on the final product and by reducing the total cost, producers have an opportunity to increase its profit margin.

Thirdly, there was pre and post harvesting loss due to poor handling techniques and storage facilities of their perishable products at farm and during transportation in the study areas.

Fourthly, there was no further significant processing of the produce in the study areas to increase creation of value in order to increase benefit obtained \& maximizing consumer satisfactions on horticultural crops productivity. Additionally, there was no standardization of horticultural crops product based up on different criteria such as size, quality, nutritional value and etc.

Lastly, constraints were often include sufficient technical, business or financial support services, regulatory framework, poor public infrastructure (roads, telecommunications, electricity, etc.), a lack of information about or weak connections to end markets, and/or inadequate coordination between firms. Thus, there could be a need of recommendations and are presented under the fifth chapter.

\section{Summary, CONCLUSION AND RECOMMENDATIONS}

\subsection{Summary and Conclusion}

The agricultural sector in Ethiopia is the mainstay of the country`s economy. Agriculture contributes $41 \%$ to GDP and more than $85 \%$ of employment opportunities for labor force. Horticulture plays a multiple and important role in food systems and for food security, socio-economic and environmental sustainability. This is due to the horticultural crops are well suited for cultivation in environmental conditions where other crops may fail and their diversity to be produced in different agro-ecologies and seasonal cycle. Horticulture sector is also an important in that it generates more employment opportunities, an important source of energy, contributes in alleviating poverty, high output per unit area and it`s a well balanced crop with good ratio between chemical compositions.

However, diseases, drought, insects (pests) and lack of sufficient irrigation water were the major naturally occurring production constraints of horticultural crops production in the study areas. Additionally, limited knowhow and skill on agronomic practices and limited supply of agricultural inputs were identified as production constraints. Low price of produce at peak harvesting time, poor linkage with different sectors/actors and perishability nature (loss of produce) are also identified as major marketing constraints of producers in the study areas. Lack of credit; supply shortage; lack of organized market information; low quality of produce; horticultural produce loss; competition with unlicensed traders; price fluctuation; and lack of support from concerned government bodies were major marketing constraints faced by producers raised by households during 2016/17 production year in the study areas.

Thus, from the study results it is possible to conclude that, even though there were potential conditions for horticultural crops production in the study areas; the sector was constrained by different production and marketing related problems like diseases, drought, insects (pests) problems, lack of sufficient irrigation water, limited access to supply of agricultural inputs, lack of adequate extension services, poor linkage with value chain actors, loss of produce, low produce quality and price fluctuation. Horticultural crops production and marketing related of the producers are affected by several aforementioned constraints at farmers and supply to the market those influenced the efficiency and competitiveness of the sector within the community in the study areas. Therefore, it is concluded that intervention is required to improve the efficiency of horticultural crops productivity and quality in the study areas and the like. 


\subsection{Recommendations}

Based on the summarized findings and conclusions of the study, the following recommendations are forwarded in order to improve the production and productivity of horticultural crops in the study areas and similar environments.

The use of improved inputs affected the production and market supply positively and significantly in the study areas. As a result, the distribution of improved seeds, inorganic fertilizers, irrigation systems, pesticides, insecticides and other agronomic and cultural practices and management systems to farmers will help the producer to supply more to the market to incur money and family consumption. It's advisable to provide improved inputs to the farmers at the time where the farmers need in adequate manner at a reasonable price and place.

The farmers have to develop improved and affordable post harvest handling and storage techniques to prolong the shelf life of horticultural products and minimize post harvest losses.

The different horticultural crops stake holders have to build the capacity of producer`s cooperatives. Hence, the cooperatives will provide much better opportunities for integrating the farmers into horticultural crops production and supply to markets so that the profit margins of the producer will be improved as well.

By undertaking research and development on improved seed varieties in the study areas, different stake holders of the value chain such as Arsi University, Kulumsa Agricultural Research Center and others should facilitate and support the provision and diffusion of improved seed supply through demonstration and multiplication of improved seed varieties.

The quantity of horticultural crops produced is affecting the marketable supply of the produce positively. Therefore, the government policy should have to target on raising the production and productivity of crops of the horticulture sector; encouraging and supporting farmers in using of new technologies, creating sustainable and stable demand for the produced would also encourage farmer's decision on horticultural crops production to produce more quantity and quality produces.

Lack of training of farmers also significantly affecting the households producing capacity of them as it is expected to increase the production and market supply of farmers. But, the study result indicated that household's training and extension accesses have insignificant impact on production and market supply of horticultural crops. Hence, its recommended that expanding an extension and training services will help the farmers to increase their production and market supply of the commodity without much losses. Also, offering marketing information for farmers (in-service information) will help the producers to gain a practical knowledge and skill on the current inputs supply and produces marketing chain and technologies to be utilized for production and trading their commodities.

The focal group discussions results indicated that the selling price affected the volume of horticultural crops supplied to the market positively and significantly. Farmers in the study areas increased market supply whenever there was high selling price. As a result, the concerned bodies have to regulate and do much work on keeping the price of horticultural commodities either at increasing or existing prices of each at each market level.

\section{REFERENCES}

[1] Abay, A. 2007. Vegetable marketing chain analysis in the case of Fogera Wereda, in Amehara National regional state of Ethiopia. An M.Sc. Thesis Presented to the School of Graduate Studies of Haramaya University, Ethiopia. Pp 41-87.

[2] Abraham Tegegn. 2013. Value chain analysis of vegetables: the case of Habro and Kombolcha woreda in Oromia region, Ethiopia. An M.Sc. Thesis presented to the school of graduate studies, Haramaya University, Ethiopia. Pp45.

[3] Adugna, G. 2009. Analysis of fruit and vegetable market chains in Alamata, Southern zone of Tigray: the case of onion, tomato and papaya. Haramaya University, Ethiopia. Pp 14-80.

[4] Alemayehu, N., Hoekstra, D., Berhe, K. and Jaleta, M. 2010. Irrigated vegetable promotion and expansion: The case of Ada'a District, Oromia Region, Ethiopia. Improving the productivity and market success of Ethiopian Farmers (IPMS), Case Study Report, International Livestock Research Institute (ILRI), Addis Ababa, Ethiopia. Downloadable at: http://cgspace.cgiar.org/handle/10568/1422, accessed on February 11, 2014. 
[5] Astewel Takele, 2010. Analysis of rice profitability and marketing chain: The case of Fogera woreda, South Gondar Zone, Amhara National Regional State, Ethiopia. An M.sc thesis presented to School of Graduate Studies, Haramaya University, Ethiopia. Pp 76.

[6] ATA (Agricultural Transformation Agency). 2014. Transforming Agriculture in Ethiopia, Annual Report. Pp 3-8.

[7] Ayelech, T. 2011. Market chain analysis of fruits for Gomma woreda, Jimma Zone, Oromia National Regional State. M.Sc. Thesis presented to School of Graduate Studies, Haramaya University, Ethiopia. Pp110

[8] Baredo, Y. 2013. Gamo Gofa Zone Diagnosis and Planning Document, Livestock and Irrigation Value Chains for Ethiopian Smallholders (LIVES) Project. Pp 16-18.

[9] Belay, D., Getachew, E., Azage, T. and Hegde, B.H. 2013. Farmers' perceived livestock production constraints in Ginchi watershed area: Result of participatory rural appraisal. Academic Journal, 4(8): 128134.

[10] Bezabih, E. 2008. Participatory value chain analysis of horticultural crops in kombolcha district of eastern Oromia, Ethiopia, research report, actionaid Ethiopia, Addis Ababa. Pp 48-70

[11] Bezabih, E. 2010. Market Assessment and Value Chain Analysis in Benishangul Gumuz Regional State: Final Report Ethiopia. Pp 1-2.

[12] Bezabih, E. and Hadera, G. 2007. Constraints and Opportunities of Horticulture Production and Marketing in Eastern Ethiopia. DCG Report No. 46.Pp 36- 43.

[13] Biruhalem Kassa. 2010. Rice value chain in Metema district, North Gondar, Ethiopia: Challenges and Opportunities for innovation. An M. Sc. Thesis presented to the School of Graduate Studies of Addis Ababa University. Addis Ababa. Pp 54.

[14] Biruk Seifu. 2013. The assessment of root crops contribution to household food security: The case of Soddo Zuria Woreda, Wolaita Zone, SNNPR, Ethiopia. An M.Sc. Thesis presented to the School of Graduate studies of Addis Ababa University. Addis Ababa. Ethiopia.

[15] Central Statistics Agency of Ethiopia. 2011. Annual Area and Production of Major crops.Vol.1.

[16] CSA (Central Statistics Agency). 2014. Agricultural sample survey, 2013/2014, report on crop and live stock product utilization (private peasant holdings,meher season). Statistical Authority, Addis Ababa, Ethiopia. Pp 11-26

[17] Ison, R.L. and Ampt, P.R. 1992. Rapid Rural Appraisal: A Participatory Problem Formulation Method Relevant to Australian Agriculture. Agricultural Systems, 38: 363-386.

[18] Dolan, C. and Humphrey, J. 2004. Changing Governance Patterns in the Trade in Fresh Vegetables between Africa and the United Kingdom. Journal of Environment and Planning, 36: 491-509.

[19] EHDA (Ethiopian Horticulture Development Agency). 2011. Exporting fruit and vegetable from Ethiopia. Assessment of development potentials and investment options in the export-oriented fruit and vegetable sector. Addis Ababa, Ethiopia. Pp 15-51

[20] FAO (Food and Agriculture Organization). 2003. Analysis of the food consumption of Japanese households. Economic and Social Development Paper No 152. Rome, Italy. Pp 72.

[21] Hung, H.C., Joshipura, K.J., Jiang, R., Hu, F.B., Hunter, D., Smith-Warner, S.A., Colditz, G.A., Rosner, B., Spiegelman, D. and Willett, W.C. 2004. Fruit and vegetable intake and risk of major chronic disease. Journal of the National Cancer Institute, 96(21): 1577-1584.

[22] Kindei, A. 2007. Sesame market chain analysis: the case of Metema Woreda, North Gondar Zone, Amhara National Regional State. An M.Sc. Thesis Presented to School of Graduate Studies of Haramaya University. Pp123

[23] Mekonnen, F. 2012. Zonal diagnosis and intervention plan West Shoa, Oromia. Available: http://livesethiopia.wikispaces.com/file/view/West+shoa+diangosis+report+16042013.pdf. Accessed $10 / 26 / 14$.

[24] Munguzwe, H. and Tschirley, D. 2006. Policy synthesis food security research project. Ministry of Agriculture and Cooperatives. Agricultural Consultative Forum, Michigan State University and Market Access and Trade Enabling Policies (MATEP) Programme, Lusaka, Zambia.

[25] New, S.A., Robins, S.P., Campbell, M.K., Martin, J.C., Garton, M.J., Bolton-Smith, C., Grubb, D.A. and Lee, S.J. 2000. Reid DM: Dietary influences on bone mass and bone metabolism: further evidence of a positive link between fruit and vegetable consumption and bone health? American Journal Clinical Nutrition, 71: 142-151.

[26] Rasmussen, M., Krolner, R., Klepp, K.I., Lytle, L., Brug, J., Bere, E. and Due, P. 2006. Determinants of fruit and vegetable consumption among children and adolescents: A review of the literature. Part I: Quantitative studies. International Journal of Behavioral Nutrition and Physical Activity, 3(1): 22. 
[27] Ruel, M.T., Minot, N. and Smith, L. 2005. Patterns and determinants of fruit and vegetable consumption in sub-Saharan Africa: a multicountry comparison. World Health Organization (WHO), Geneva. Pp 45.

[28] Tewodros Bezu, Kebede Woldetsadik and Tamado Tana. 2014. Production scenarios of Mango (Mangifera indica L) in Harari regional State, Eastern Ethiopia. Presented to the school of plant sciences, college of agriculture and environmental sciences, Haramaya University, Ethiopia.

[29] UNIDO (United Nations Industrial Development Organization). 2009. Agro-value chain analysis and development: a staff working paper, Vienna. Pp 4-5.

[30] Van't Veer, P., Jansen, M.C., Klerk, M., and Kok, F.J. 2000. Fruits and vegetables in the prevention of cancer and cardiovascular disease. Journal of Public Health Nutrition, 3(1): 103-107.

[31] Weignberger, K. and Lumpkin, A. 2005. Horticulture for poverty alleviation: The unfunded revolution: The World Vegetable Centre, AVRDC Publication No. 05-613, Shanhua, Taiwan. Pp19.

[32] WB (World Bank). 2006. Burden of Disease/Comparative Risk Assessment. Washington DC, 20433.

[33] WHO (World Health Organization). 2003. Diet, nutrition and the prevention of chronic diseases. Report of a joint WHO/FAO expert consultation. WHO Geneva.

Citation: Diriba-Shiferaw G., Hailu-Duguma M., Mebrat Tola, "Horticultural Crops Production Potentials and Challenges Assessment in Arsi Zone, Oromia-Ethiopia”, International Journal of Forestry and Horticulture, 6(4), pp. 24-41. DOI: https:// doi.org/10.20431/2454-9487.0604004

Copyright: () 2020 Authors, this is an open-access article distributed under the terms of the Creative Commons Attribution License, which permits unrestricted use, distribution, and reproduction in any medium, provided the original author and source are credited. 